\title{
Energy Efficiency Assessment of the Housing Stock in Belarusian Regions
}

\author{
Volha Kameka \\ Department of Economics \\ Polotsk State University \\ Novopolotsk, Belarus \\ o.kamecko@psu.by
}

\author{
Svetlana Izmailovich \\ Department of Economics \\ Polotsk State University \\ Novopolotsk, Belarus \\ s.izmailovich@psu.by
}

\author{
Alena Lisichonak \\ Department of Economics \\ Polotsk State University \\ Novopolotsk, Belarus \\ l.lisichonok@psu.by
}

\begin{abstract}
The need to ensure energy efficiency of the Belarusian economy at the present stage is justified. Indicators characterizing the level of fuel energy consumption and the impact of fuel consumption on the environment for the Belarusian regions are calculated. The authors found that Vitebsk region is characterized by high heat capacity Gross regional product. Also, Vitebsk region is characterized by a high volume of pollutant emissions into the air. We are talking about the emissions generated from fuel combustion for the production of heat and electricity. It has been substantiated that the main directions of regional development should be to reduce the consumption of fuel resources and the volume of emissions. The authors analyzed the structure of final consumption of fuel and energy resources by sectors of consumption, which showed that the main consumers of fuel and energy resources in Belarus are industry and housing sector.

In this article the highest priority has been given by authors to energy efficiency in housing sector. It is noted that improving the energy efficiency of the housing stock can reduce the energy load on the region. It is proposed to use a system of indicators to assess the level of energy efficiency. The scientific novelty is in the application of a systematic approach to assessing energy efficiency. Previous studies were limited to considering individual energy efficiency indicators, rather than their systems. It is proposed to include the following groups of indicators in the system: technical, financial and economic, environmental. In contrast to the previously proposed groups of indicators, the system developed by the authors includes environmental indicators. The relevance of their study is due to regional characteristics, which is especially important for the Vitebsk region.

The proposed system of indicators is able to give a holistic view of the level of energy efficiency of the housing stock. Thus, it becomes possible to identify reserves for the growth of energy efficiency in the housing sector in Belarus.
\end{abstract}

Keywords - Energy efficiency, housing stock, region

\section{INTRODUCTION}

Specific conditions for the functioning of economic systems, features of the development of the energy sector and current trends in the development of the world economy against the background of global fuel, energy and environmental problems ensure the relevance of the problem of ensuring energy efficiency at various levels of the economy. The state policy of Belarusian transition to the path of innovative resource-saving and energysaving development, which allows the implementation of the strategy of energy efficiency, energy conservation and energy substitution in these conditions is completely justified and has no alternative. This is enshrined in a number of regulatory legal acts, including the Concept of the National Strategy for Sustainable Development of the Republic of Belarus for the period up to 2035 [1], the Law of the Republic of Belarus "On Energy Saving" [2], etc.

The priorities of resource-saving and energy-saving development were selected based on quite obvious arguments [3, 4]:

- in terms of the GPD energy intensity (in terms of purchasing power parity), Belarus was among the countries with an inefficient economy;

- electrical energy has taken a key place in the material foundation of modern society;

- thermal energy in the required amount is a fundamental condition for a comfortable life of the population;

- sustainable growth in the welfare of society is possible only with a decrease in the growth rate of specific volumes of energy consumption;

- large-scale replacement of non-renewable mineral energy resources with renewable ones, and traditional technologies for the production of electric and thermal energy with advanced ones allows extending the availability of traditional energy resources, reducing man-made pressure on the environment.

A number of scientists are developing the theory and 
methodology, specific methodological tools for ensuring the energy efficiency of the Belarusian economy: T.G. Pospelova, N.A. Haustovich, T. Kh. Gulbrandsen, L.P. Padalko, V.L. Chervinsky, V.L. Ganzha, I.V. Galuzo, I.N. Potapov, V.A. Baydakov [5-9] and other scientists.

Due to the high degree of relevance, the problem of improving energy efficiency is being studied by different scientists and scientific teams: AH Rosenfeld, M. Patterson, R. Haas, TR Lakshmanan, S. Ratick, H. Herring, S. Sorrel, V. V. Efremov, G.Z. Markman, I. A. Bashmakov, R. F. Araslanov, A. A. Tupikina, A. S. Gorshkov, A. A. Gladkikh and others [10-20].

Most of these scientists consider this concept as a category that determines the efficiency of the fuel and energy complex in the context of reducing the consumption of fuel and energy resources. The housing stock, due to the use of various types of energy, can affect the volume of its output, thereby indirectly affecting the process of consumption of fuel and energy resources. A number of researchers consider energy efficiency as a characteristic of production processes, including: output of products by evaluating the efficiency of energy costs to the production result. Within the framework of the housing stock, it is possible to conduct a reverse assessment related to the economy of energy resources through the production of measures that improve the quality of life of the population, including the quality of functioning of the housing stock. For example, to determine the need for heat energy after the implementation of major repairs in the housing stock. This will allow us to determine the energy savings required for heating a residential space, both for the end user and for the production process of the heat generating plant. Thus, the derived category should include the most rational ideas of the above and take into account the scope of application (housing stock) as the final factor.

The results of the research carried out by the World Bank, the United Nations Development Program and other international organizations are of great practical and scientific importance. The research in the field of energy efficiency in various countries and regions is carried out by leading international organizations: the European Commission, the International Energy Agency, etc.

For example, the World Bank actively contributes to the implementation of programs to improve the energy efficiency of the world's regions, including their housing stock. "Despite the huge potential, the potential for energy efficiency is still not fully realized due to political, technical and financial difficulties”. [21]

Countries and development organizations, such as the World Bank Group, have realized that long-term efforts are needed to successfully implement large-scale energy efficiency programs. Financing needs to be tailored to the needs of local markets, while relying on effective policy measures, regulatory measures and, in some cases, incentives.
Countries are currently developing next-generation programs to realize this huge potential, including through combined purchases of energy-saving devices and equipment, creating revolving funds, and improving national standards.

The policy of the European Union in the field of energy efficiency of the housing stock is based on regional characteristics.

Countries with cold climates traditionally pay more attention to general energy efficiency issues compared to countries with more favorable climatic conditions, which mainly focus on reducing the energy consumption spent on air cooling. Germany, France, and the United Kingdom are among the leaders in implementing a consistent energy policy, and Denmark and some new EU members, such as Slovenia, are also very active in these issues. [22]

As areas that require special attention in the context of energy efficiency of the housing stock, it is possible to determine the level of energy consumption of various engineering networks, the energy characteristics of buildings, the share of renewable energy sources, etc. In order to improve the energy efficiency of housing facilities, European CEN standards have been developed.

National Academy of Sciences of Belarus, Ministry of Energy, Ministry of Architecture and Construction, Ministry of Housing and Utilities, Ministry of Industry, Ministry of Natural Resources and Environmental Protection, the Ministry of Economy deal with the problems of sustainable development of the energy sector and energy efficiency by types of economic activity, increasing social stability, economic development, as well as issues of state regulation of energy efficiency at the level of the Republic of Belarus. Research institutes and institutions of higher education make a significant contribution to the development of these issues.

\section{MATERIALS AND METHODS}

The purpose of the study is to develop a system of indicators for assessing the energy efficiency of the housing stock of Belarusian regions.

More specifically, the study aims to analyse the regional characteristics to substantiate directions for increasing energy efficiency to study the housing stock as the main consumer of energy in Belarus; to form groups of indicators for assessing the energy efficiency of the housing stock.

In the process of the research, the authors used the following methods: analysis, synthesis, observation, comparison, a systematic approach, as well as special methods and techniques of economic analysis.

In order to identify regional characteristics of consumption of fuel and energy resources and its impact on the environment, the authors have calculated indicators based on official data of the National Statistical Committee of Belarus. The choice of indicators is determined by many years' experience of assessment at the national level and the possibility of 
their adaptation to the regions.

Comparison of the indicators obtained for the regions of Belarus allowed revealing the peculiarities of resource consumption in the Vitebsk region.

\section{RESULTS AND DISCUSSION}

There are seven regions in Belarus: Brest, Vitebsk, Gomel, Grodno, Minsk, Mogilev regions and Minsk the capital city. Reasons for the considerable attention to the Vitebsk region:

- unfavourable environmental situation due to significant amounts of pollutants emitted into the atmosphere;

- the region is located in a colder climatic zone than other regions, which affects the performance of the housing stock and the consumption of fuel and energy resources.

To improve energy efficiency, it is necessary to take into account regional characteristics that have a direct impact on it. To do this, we will calculate the indicators characterizing the level of consumption of fuel and energy resources and the impact of fuel consumption on the environment of the Belarusian regions based on the data of the National Statistical Committee of Belarus in 2019 (Table 1).

The gross regional product of Gomel region is the most power-consuming, and the gross regional product of Vitebsk region is heat-consuming. Most of all electricity is consumed per capita in Gomel region, and the least - in Brest region.

The emissions of pollutants into the air from fuel combustion in the process of heat and electricity production per capita are the most significant in 2019 in Vitebsk region. The value of this indicator per unit of territory is the highest in Minsk region. Vitebsk region has a lower level of this indicator, slightly inferior to Minsk region.

TABLE I. INDICATORS CHARACTERIZING THE LEVEL OF CONSUMPTION OF FUEL AND ENERGY RESOURCES AND THE IMPACT OF FUEL CONSUMPTION ON THE ENVIRONMENT

\begin{tabular}{|c|c|c|c|c|c|c|}
\hline \multirow[t]{2}{*}{ Indicator name } & \multicolumn{6}{|c|}{ Indicator value by region } \\
\hline & Brest & Vitebsk & Gomel & Grodno & Minsk & Mogilev \\
\hline $\begin{array}{l}\text { 1. Electricity of } \\
\text { the gross } \\
\text { regional product, } \\
\text { kilowatt-hours } \\
\text { per } 1 \text { ruble }\end{array}$ & 0,26 & 0,49 & 0,63 & 0,41 & 0,23 & 0,42 \\
\hline $\begin{array}{l}\text { 2. Heat capacity } \\
\text { of gross regional } \\
\text { product, } \\
\text { gigacalories per } \\
1,000 \text { rubles }\end{array}$ & 0,45 & 0,86 & 0,78 & 0,71 & 0,37 & 0,69 \\
\hline $\begin{array}{l}\text { 3. Electricity } \\
\text { consumption per } \\
\text { capita, thousand } \\
\text { kilowatt-hours }\end{array}$ & 2,42 & 4,29 & 6,10 & 4,33 & 3,78 & 3,76 \\
\hline $\begin{array}{l}\text { 4. Emissions of } \\
\text { pollutants into } \\
\text { the atmosphere } \\
\text { from ruel } \\
\text { combustion in }\end{array}$ & 6,52 & 20,87 & 8,07 & 7,11 & 7,42 & 8,00 \\
\hline
\end{tabular}

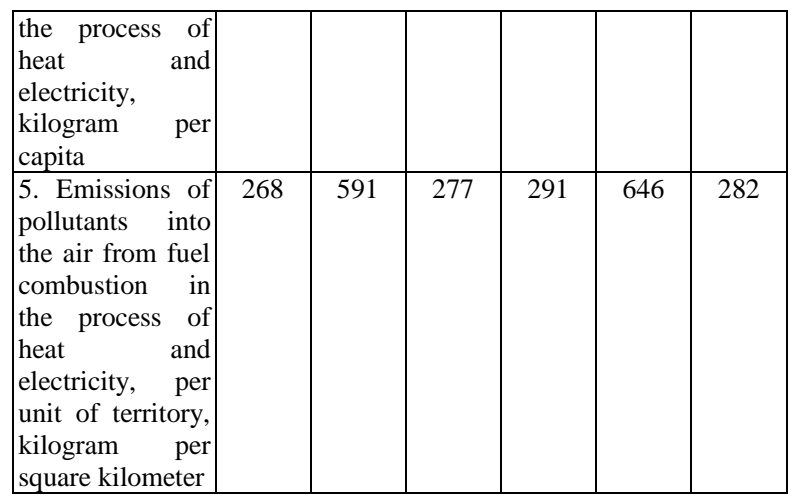

Thus, it can be concluded that Vitebsk region is distinguished by a high level of heat capacity of the gross regional product and the volume of emissions of pollutants into the air from fuel combustion in the process of heat and electricity production. Consequently, the main directions for the development of the region should be to reduce the consumption of fuel resources and reduce the volume of emissions.

In order to identify the ways for reducing the consumption of fuel and energy resources, it is necessary to consider the structure of the final consumption of fuel and energy resources by consumption sectors in 2010 and 2019 (Table 2).

So, the main consumer of fuel and energy resources in Belarus is industry. The next major consumer is the housing sector. These sectors account for more than 60 $\%$ of all final consumption of fuel and energy resources. Transport also accounts for a significant share in final consumption. All the above-mentioned sectors of consumption account for $4 / 5$ of the total volume of final consumption. At the same time, noteworthy is the fact that, if the share of consumption in industry and the housing sector decreased in 2019 compared to 2010, then in transport it increased significantly.

TABLE II. STRUCTURE OF FINAL CONSUMPTION OF FUEL AND ENERGY RESOURCES BY CONSUMPTION SECTORS IN 2010 AND 2019 (IN PERCENTAGE OF THE TOTAL)

\begin{tabular}{|c|c|c|c|}
\hline \multirow{2}{*}{ Consumption sector } & \multicolumn{2}{|c|}{$\begin{array}{c}\text { Share of } \\
\text { consumption, } \\
\text { percent }\end{array}$} & \multirow{2}{*}{$\begin{array}{c}\text { Change in the } \\
\text { share in } 2019 \\
\text { compared to } \\
2010, \\
\text { percentage } \\
\text { points }\end{array}$} \\
\hline & 2010 & 2019 & \\
\hline 1. Industry & 34,5 & 33,1 & $-1,4$ \\
\hline $\begin{array}{l}\text { 2. Agriculture, forestry } \\
\text { and fisheries }\end{array}$ & 5,9 & 6,3 & 0,4 \\
\hline 3. Service sector & 10,1 & 9,8 & $-0,3$ \\
\hline 4. Construction & 1,7 & 0,9 & $-0,8$ \\
\hline 5. Transport & 19,8 & 23,2 & 3,4 \\
\hline 6. Housing sector & 28,0 & 26,7 & $-1,3$ \\
\hline
\end{tabular}

Thus, in order to reduce the consumption of fuel and energy resources, it is necessary to focus on the following sectors of the economy in Belarus: industry, transport and housing sector. 
In this article, the authors take a closer look at energy efficiency in the housing sector.

The housing stock is one of the objects with the greatest potential in terms of energy efficiency. Based on the works of different scientists, it is clear that high indicators of real economic growth require consistent and rational measures to create industrial enterprises of a new formation, as well as to improve the existing production capacities in various sectors of the economy. The central place here is occupied by the state program "Energy Saving", which has been developed in the Republic of Belarus for a five-year period. Currently, a program for 2021-2025 is being prepared. It aimed at improving the energy efficiency of the housing stock.

It should be noted that the housing sector is a specific field of activity, which has a number of features. This area is directly related to the level and quality of life of people. An important task of the housing stock is to provide the population with living space. Also, the housing stock is located at the junction of two areas of activity: housing construction and housing and communal services. At the initial stage of the residential buildings are residential, and the phase of the object relate to housing and utilities. Among other things, this sector requires efficient operation and timely maintenance, which is also a feature.

Along with other subjects of the national economy of Belarus, the housing stock is one of the largest energy consumers. The process of improving the energy efficiency of residential sector is possible by reducing the amount of energy consumed, which entails a significant reduction in the consumption of fuel and energy resources for energy production.

Improving the quality of energy production and usage (primarily electricity and heat) is the basis for determining the energy efficiency of the housing stock. For a rational assessment of the energy efficiency of objects, we suggest using energy efficiency indicators.

According to the Law of the Republic of Belarus "On energy saving", the energy efficiency indicator is a scientifically validated absolute or specific consumption of fuel and energy resources (including their normative losses) on the unit of production (works, services) for any purpose set of technical normative legal acts in the field of technical regulation and standardization [2].

The task of determining the optimal energy efficiency indicators is relevant for the development of energy consumption standards that adequately reflect the technological process or the chain of successive technological processes [16]. However, in the issue of housing stock, not only the technologies of production and development of heat and electricity are important, as well as the condition and energy demand of the fund's facilities themselves, the effectiveness and economic effect of measures to improve the energy efficiency of residential buildings.

The environmental issue is also important: namely the influence of the weather and natural features of the region on the volume of energy production and consumption, as well as the impact of energy producers and consumers on the environment. Thus, the most rational approach is to form a system of indicators for assessing energy efficiency in relation to the functioning of the housing stock.

Based on the research of R. Kaplan and D. Norton [23], the balanced scorecard provides management with a universal mechanism that interprets the company's worldview and strategy through a set of interdependent indicators. Within the framework of the functioning of the housing stock, this kind of indicator system demonstrates the versatility of energy efficiency, claiming that all its indicators are inherently interdependent. Thus, they can be divided into three main groups: technical, financial and economic, and environmental. Also, if necessary, it is possible to allocate related groups: technical-economic and economic-environmental indicators.

The group of technical indicators combines indicators of the technical condition of housing facilities and energy supply systems for these facilities, as well as parameters related to the technological process of production and consumption of various types of energy. This group of indicators takes into account the efficiency of consumption of fuel and energy resources, energy efficiency of power transfer, energy intensity of its production, energy consumption standards, thermal characteristics of housing facilities, etc. The calculation of technical indicators gives an idea of the volume of energy consumption, expressed in natural units of measurement (units of the volume of conventional fuel, etc.), as well as the state and characteristics of the housing stock objects under consideration.

Financial and economic indicators are designed to reflect the economic effect of measures to improve the energy efficiency of housing facilities. These indicators include net profit, profitability and payback period of measures (simple and discounted), resource savings (expressed in monetary units), the impact of reducing energy consumption by the housing stock on the level of gross domestic product in the country, and other indicators that are necessary for the purposes of the study.

Within the framework of the system of energy efficiency indicators, the environmental issue of the functioning of the housing stock is also considered. This group of indicators shows the impact of the production and use of various types of energy on the environmental situation in the region, and also allows to evaluate the effectiveness of measures to improve the energy efficiency of the housing stock in the region. The group of environmental indicators includes: the specific indicator of emissions, discharges, pollutants into the atmosphere; the indicator of the use of renewable energy sources for housing stock; indicator of the efficiency of the use of natural resources, etc. 
TABLE III. COMPOSITION OF ENERGY EFFICIENCY INDICATORS OF THE HOUSING STOCK (BY GROUPS)

\begin{tabular}{|c|l|}
\hline $\begin{array}{c}\text { Name of the } \\
\text { group }\end{array}$ & \multicolumn{1}{c|}{ Indicators } \\
\hline \multirow{2}{*}{ Technical } & $\begin{array}{l}\text { - account the efficiency of consumption of fuel and } \\
\text { energy resources; } \\
\text { - energy efficiency of power transfer; } \\
\text { - energy intensity of its production; } \\
\text { - energy consumption standards; } \\
\text { - thermal characteristics of housing facilities, etc. }\end{array}$ \\
\hline $\begin{array}{c}\text { Financial } \\
\text { and } \\
\text { economic }\end{array}$ & $\begin{array}{l}\text { - net profit; } \\
\text { - profitability and payback period of measures; } \\
\text { - resource savings (expressed in monetary units); } \\
\text { - the impact of reducing energy consumption by the } \\
\text { housing stock on the level of GDP, etc. }\end{array}$ \\
\hline $\begin{array}{l}\text { Environment } \\
\text { al }\end{array}$ & $\begin{array}{l}\text { - the specific indicator of emissions, discharges, } \\
\text { pollutants into the atmosphere; } \\
\text { - the indicator of the use of renewable energy } \\
\text { sources for housing stock; } \\
\text { - using of natural resources, etc. }\end{array}$ \\
\hline
\end{tabular}

Such formation of groups of energy efficiency indicators allows us to take into account all stages of the life cycle of energy consumed by the housing stock: to take into account the conditions and technology of production of energy resources, to reflect the financial side of this issue.

\section{CONCLUSIONS}

The authors substantiate the need to take into account regional peculiarities in the management of energy efficiency of housing sector. For example, Vitebsk region is characterized by a high level of heat capacity of the gross regional product and a significant amount of emissions of pollutants into the atmosphere from the combustion of fuel in the process of heat and electricity production. This determines the need to develop specific recommendations for improving energy efficiency in this region.

It is proved that one of the main consumers of fuel and energy resources in the Republic of Belarus is the housing sector. Therefore, it is necessary to look for reserves to improve energy efficiency in the region.

The need to increase the level of energy efficiency of the housing stock determines the need for its assessment. The authors propose a system of indicators for assessing the energy efficiency of the housing stock, which, in contrast to the approaches proposed by other authors, includes 3 groups of indicators: technical, financial, economic and environmental. At the same time, the authors focus on the need to take into account regional characteristics when assessing energy efficiency.

The proposed system of indicators will allow not only to comprehensively assess the energy efficiency of the housing stock, based on regional characteristics, but also to develop the most accurate recommendations for each individual region, taking into account its strengths and weaknesses.

\section{REFERENCES}

[1] Concept of the National Strategy for Sustainable Development of the Republic of Belarus for the period up to 2035 [Online].
Available: $\quad$ https://www.economy.gov.by/uploads/files/Obsug daemNPA/Kontseptsija-na-sajt.pdf [Accessed January 21, 2021].

[2] Law of the Republic of Belarus “About energy saving” [Online]. Available: http://energoeffekt.gov.by/downloads/ laws/act/201501_law.pdf [Accessed January 21, 2021].

[3] E. Volkov and V. Kostuk, "New technologies in the Russian electric power industry," Bulletin of the Russian Academy of Sciences, vol.79, no. 8, pp. 675-686, 2009.

[4] S. Voronin and A. Kalinin, "Energy saving”, Zernograd, Azov Black Sea State Agroengineering Academy, 256 p., 2009.

[5] I. Galuzo, I. Potapov and I. Baydakov, "Experimental elective course "Fundamentals of Energy Efficiency" for schoolchildren," Energy Efficiency, no. 8, 24 p., 2005.

[6] V. Ganzha, "Fundamentals of efficient use of energy resources: theory and practice of energy saving,” Minsk, Belarusian. Science, 451 p., 2007.

[7] T. Gulbrandsen, L. padalko and V. Chervinsky, "Energy efficiency and energy management: study guide,” Minsk, BGATU, 240 p., 2010.

[8] T. Pospelova, "Fundamentals of energy saving," Minsk, UP "Technoprint", 353 p., 2000.

[9] N. Khaustovich, "Energy efficiency as an important condition for sustainable development of the country's economy," Belarusian Economic Journal, no. 3, pp. 15-23, 2006.

[10] R. Haas, "Energy efficiency indicators in the residential sector," Energy Policy, no. 25 (7-9), pp. 789-802, 1997.

[11] H. Herring and S. Sorrel, "Energy Efficiency and Sustainable Consumption: The Rebound Effect," Hampshire, Palgrave Macmillan, 272 p., 2009.

[12] T. R. Lakshmanan, P. Nijkamp and S. Ratick, "Integrated Models for Economic-Energy-Environmental Impact Analysis. EconomicEnvironmental-Energy Interactions: Modeling and Policy Analysis,” Springer Netherlands, pp. 7-39, 1980.

[13] M. Patterson, "What is energy efficiency?" Energy Policy, no. 24(5), pp. 377-390, 1996.

[14] A. H. Rosenfeld, "The Art of Energy Efficiency: Protecting the Environment with Better Technology,” Annual Review of Energy and Environment, no. 24, pp. 33-82, 1999.

[15] A. H. Rosenfeld, "Real Prospects for Energy Efficiency in the United States, Chaired by Lester Lave and Maxine Savitz, America's Energy Future Panel on Energy Efficiency Technologies," National Academy of Sciences, Academy of Engineering; The National Academies Press., 203 p., 2009.

[16] V. Efremov, G. Markman ""Energy saving" and "energy efficiency": clarification of concepts, the system of balanced indicators e "energy efficiency"," Bulletin of the Tomsk Polytechnic University, no. 4, pp. 146-148, 2007.

[17] A. Araslanov, "Formation of the mechanism of energy efficiency management of socio-economic systems of the region" [Online]. Available: https://esstu.ru/library/free/ Avtoreferat /\% d0\% 90\% d1\% 80\% d0\% b0\% d1\% 81\% d0\% bb\% d0\% b0\% d0\% bd\% d0\% be $\%$ d0\% b2_\% d0\% a 0_\% d0\% a4.pdf. [Accessed January 11, 2021].

[18] I. Bashmakov, "Energy efficiency: from rhetoric to action" [Online]. Available: https://www.abok.ru/?controller=article AuthorView\&id=1467 [Accessed December 12, 2020].

[19] A. Gorshkov and A.Gladkikh, "Measures to improve energy efficiency in construction,” Construction sciences: building telophysics and energy saving, no. 3, pp. 246-250, 2010.

[20] A. Tupikina, "Energy saving and increasing energy efficiency: a history of concepts,” Business. Education. Right. Bulletin of the Volgograd Institute of Business, no. 2, pp. 90-95, 2014.

[21] "Energy efficiency" [Online]. Available: https://www.vsemi rnyjbank.org/ru/results/2017/12/01/energy-efficiency [Accessed March 1, 2021].

[22] O. Seppanen, "Energy efficiency requirements for buildings in the EU” [Online]. Available: https://www.abok.ru/for_spec/ articles.php?nid=4739 [Accessed February 19, 2021].

[23] R. S. Kaplan and D. P. Norton, "A balanced scorecard. From strategy to action,” Moscow, Olimp-Business, 304 p., 2003.

[24] Energy balance of Belarus, 2020: statistical bulletin [Online]. Available: https://www.belstat.gov.by/ofitsialnaya-statistika/ realny-sector-ekonomiki/energeticheskaya-statistika /statisti cheskie-izdaniya/index_17875/ [Accessed December 21, 2020]. 